\title{
ANALISIS PELAYANAN DAN KEPUASAN PASIEN RAWAT JALAN DI RSI SITI KHADIJAH PALEMBANG
}

\author{
Helsy Desvitasari \\ Program Studi Ilmu Keperawatan STIK Siti Khadijah Palembang Jalan Demang \\ Lebar Daun Lorok Pakjo Palembang 30117 \\ Email: desvitasarihelsy@gmail.com
}

\begin{abstract}
Abstrak
Kepuasan pasien merupakan salah satu indikator penting yang harus diperhatikan dalam pelayanan kesehatan. Pelayanan kesehatan bermutu merupakan salah satu wujud dari tuntutan masyarakat di era millenial saat ini. penelitian ini bertujuan untuk mengetahui hubungan pelayanan terhadap kepuasan pasien rawat jalan di RSI Siti Khadijah Palembang. Penelitian ini merupakan penelitian kuantitatif deskriptif analitik dengan pedekatan cross sectional. Penelitian ini dilakukan bulan 5-26 November 2018 adapun jumlah sampel pada penelitian ini yaitu 372 orang responden yang sedang melakukan pengobatan di ruang rawat jalan RSI Siti Khadijah Palembang. Uji statistic yang digunakan adalah chi square test. Hasil penelitian ini menunjukkan bahwa sebagian besar responden yaitu sebanyak $216(58,1 \%)$ mengatakan pelayanan yang diberikan rumah sakit sudah baik serta merasa puas terhadap pelayanan yang diberikan yaitu berjumlah 196 (52,7\%) responden. Analisa bivariate menunjukkan ada hubungan pelayanan terhadap kepuasan pasien di ruang rawat jalan RSI Siti Khadijah Palembang dengan p value 0,001<0,005. Maka dari itu disarankan kepada RSI Siti Khadijah untuk dapat mempertahankan dan meningkatkan pelayanan yang lebih baik lagi melalui system informasi manajemen terpadu rumah sakit terkini.
\end{abstract}

Kata kunci : pelayanan, kepuasan pasien

\begin{abstract}
Patient satisfaction is an important indicator that must be considered in health services. Quality health services are a manifestation of the demands of society in the current millennial era. This study aims to determine the relationship between service and outpatient satisfaction at the RSI Siti Khadijah in Palembang. This research is a quantitative descriptive analytic study with a cross sectional approach. This research was conducted in 5-26 November 2018 while the number of samples in this study were 372 respondents who were doing treatment in the outpatient room of RSI Siti Khadijah Palembang. The statistical test used was the chi square test. The results of this study indicate that most of the respondents, as many as 216 (58.1\%), said the services provided by the hospital were good and were satisfied with the services provided, namely 196 (52.7\%) respondents. Bivariate analysis showed that there was a relationship between service and patient satisfaction in the outpatient room at RSI Ssiti Khadijah Palembang with a $p$ value of $0.001<0.005$. Therefore it is suggested to RSI Siti Khadijah to be able maintain and improve better services through the latest hospital integrated management information system.
\end{abstract}

Key words: service, patient satisfaction 


\section{PENDAHULUAN}

Kepuasan pasien merupakan salah satu indikator penting yang harus diperhatikan bagi penyedia pelayanan kesehatan. Kepuasan pasien adalah hasil penilaian dari pasien terhadap pelayanan kesehatan yang diberikan dengan membandingkan harapan dan kenyataan (Kotler, 2016). Dengan demikian kepuasan pasien dirumah sakit tergantung bagaimana pelayanan yang diberikan oleh pihak rumah sakit yang bersangkutan.

Pelayanan kesehatan bermutu merupakan salah satu wujud dari tuntutan masyarakat di era millenial saat ini. Masyarakat yang semakain kritis dan update terhadap informasi memaksa pelayanan kesehatan lebih responsif atas kebutuhan masyarakat. Salah satu mutu pelayanan kesehatan yang harus ditingkatkan secara berkesinambungan adalah mutu pelayanan keperawatan di rumah sakit (Nursalam 2016).

Beberapa penelitian telah membuktikan bahwa kualitas pelayanan rumah sakit sangat mempengaruhi kepuasan pasien. Penelitian Alamri dkk (2015) menunjukkan bahwa ada hubungan antara mutu pelayanan dengan kepuasan pasien dengan $\mathrm{p}$ value 0,000 di RS Islam Sitti Maryam Kota Monado. Penelitian Astuti (2017) menunjukkan bahwa Mutu pelayanan keperawatan tergolong baik dengan persentase sebesar $89,3 \%$. Tingkat kepuasan pasien tergolong cukup puas dengan persentase sebesar $68,0 \%$. Hasil penelitian menunjukkan bahwa adanya hubungan antara mutu pelayanan keperawatan dengan kepuasan pasien di RS PKU Muhammadiyah Bantul dengan nilai $\mathrm{p}=0,005$ dan nilai $\mathrm{r}=0,319$.

Pengukuran kepuasan pasien secara berkala perlu dilakukan oleh setiap rumah sakit. Hal ini disebabkan karena masyarakat semakin kritis dan semakin menuntut pelayanan yang berkualitas dari rumah sakit. Pengukuran kepuasan pasien dapat menjadi salah satu metode untuk mengetahui sejauh mana dimensi kualitas pelayanan yang telah diberikan. Hasil pengukuran tersebut dapat dijadikan sebagai referensi untuk meningkatkan kualitas pelayanan pada periode selanjutnya.

Berdasarkan laporan kunjungan pasien rawat jalan di RSI Siti Khadijah Palembang Bulan Juli - Oktober 2018, jumlah kunjungan 23.246, bulan Juli 6389 orang, jumlah kunjungan menurun di bulan Agustus menjadi 5734 orang, sedikit meningkat pada bulan September yaitu 5739 dan kembali mengalami penurunan bulan Oktober 5384 orang. RSI telah mengupayakan memberikan pelayanan kesehatan yang berkualitas, namun dalam perjalanannya masih saja mendapat keluhan dari pasien.

Penelitian ini diharapkan dapat menjadi sarana peningkatan kualitas pelayanan kesehatan kepada pasien khsusnya pasien rawat jalan.

\section{METODE PENELITIAN Jenis Penelitian}

Penelitian ini mnggunakan pendekatan Cross Sectional. untuk mempelajari dinamika korelasi dengan cara pendekatan observasi dan pengumpulan data sekaligus pada satu waktu.

\section{Waktu dan Tempat Penelitian}

Penelitian telah dilakukan pada tanggal 5-26 November 2018 bertempat di RSI Siti Khadijah Palembang.

\section{Target/Subjek Penelitian}

Populasi dalam penelitian ini berpedoman pada jumlah kunjungan pasien pada Bulan Oktober 2018 yang berjumlah 5384 orang. Adapun sampel penelitian diperoleh menggunakan teknik Accidental Sampling dengan jumlah responden sebanyak 372 orang yang melakukan rawat jalan di RSI Siti Khadijah Palembang.

\section{Prosedur}

Penelitian ini dilakukan setelah memperoleh izin penelitian dari RSI Siti Khadijah Palembang. Selanjutnya peneliti meminta izin Ka. Poli rawat jalan RSI Siti Khadijah Palembang.dlam mengumpulkan 
informasi dan data peneliti melibatkan perawat ruangan dan 2 orang relawan untuk membagikan kuesioner kepada para pasien yang melakukan pengobatan di RSI. Kemudian informasi yang diperoleh diolah dan dianalisis menggunakan program SPSS 17.

\section{Data, Instrumen dan Teknik Pengumpulan Data}

Penelitian ini menggunakan data primer yang dikumpulkan dengan cara menyebarkan kuesioner yang sudah valid dan reliable yang memuat 18 Pertanyaan.

\section{Teknik Analisis Data}

Analisa data pada penelitian ini terbagi menjadi 2 yaitu analisa univariat untuk memperoleh distribusi frekuensi dari masingmasing variable dan analisa bivariate dengan menggunakan uji cross sectional.

\section{HASIL PENELITIAN DAN PEMBAHASAN}

1. Analisis Univariat

a. Pelayanan Keperawatan

Distribusi frekuensi pelayanan keperawatan sebagai berikut :

\section{Tabel 1. Distribusi Frekuensi Pelayana} Keperawatan

\begin{tabular}{clcc}
\hline No & Pelayanan & Jumlah & Persentase \\
\hline 1. & Baik & 216 & $58,1 \%$ \\
2. & Kurang Baik & 156 & $41,9 \%$ \\
& & & \\
\hline & Total & $\mathbf{3 7 2}$ & $\mathbf{1 0 0 \%}$ \\
\hline
\end{tabular}

Berdasarkan Tabel 1 dapat diketahui bahwa dari 372 responden yang menerima pelayanan dengan baik sebanyak 216 responden $(58,1 \%)$, sedangkan pada kategori kurang baik sebanyak 156 responden $(41,9 \%)$.

Menurut Andriani dan Putra (2016), salah satu bentuk kegitan yang paling mempengaruhi kapuasan pasien di rumah sakit adalah pelayanan kesehatan professional.
Hasil penelitian ini sejalan dengan hasil penelitian Andriani, A. (2017). Bahwa dari 65 orang responden yang mendapatkan mutu pelayanan tinggi terdapat lebih dari sebagian yaitu 38 orang dengan persentase $(58.5 \%)$ mendapatkan kepuasan dan responden yang mendapatkan mutu pelayanan rendah terdapat kurang dari separuh yaitu 24 orang dengan presentase (36.9\%) mendapatkan kepuasan.

Berdasarkan penjelasan di atas, peneliti berasumsi bahwa pelayanan diruang rawat jalan RSI Siti Khadijah Palembang sudah baik, dibuktikan dengan pelayanan yang diberikan membuat keluhan pasien semakin berkurang, kesigapan perawat dan petugas kesehatan lainnya dalam pemberian asuhan sesuai dengan SOP, menciptakan ruang yang nyaman, akan tetapi pada proses administrasi masih memakan waktu. hal ini terlihat dari counter yang dibuka hanya satu pintu, lamanya proses akses data/informasi terkait pelayanan.

\section{b. Kepuasan Pasien}

Distribusi frekuensi pelayanan keperawatan sebagai berikut :

Tabel 2. Distribusi Frekuensi Pelayanan

\section{Keperawatan}

\begin{tabular}{|c|c|c|c|}
\hline No & $\begin{array}{c}\text { Kepuasan } \\
\text { Pasien } \\
\end{array}$ & Jumlah & Persentase \\
\hline 1. & Puas & 196 & $52,7 \%$ \\
\hline 2. & Kurang Puas & 176 & $47,3 \%$ \\
\hline & Total & 372 & $100 \%$ \\
\hline
\end{tabular}


Berdasarkan tabel 2 dapat dikategorikan bahwa sebanyak 372 responden $196(52,7 \%)$ yang menjawab puas, dan sebanyak $176(47,3 \%)$ responden yang menjawab kurang puas.

Menurut Purwanto (2018), Kepuasan merupakan perasaan senang, puas individu karena antara harapan dan kenyataan dalam memakai dan pelayanan yang diberikan terpenuhi. Kepuasan pasien merupakan komponen utama atau penting. Jika pasien tidak puas terhadap pelayanan keperawatan yang diberikan, dia tidak akan mencari pelayanan itu atau menerimanya, walaupun pelayanan tersebut tersedia, mudah didapat dan mudah dijangkau.

Hasil penelitian yang dilakukan Fitri (2016), tentang hubungan persepsi pasien pada pelayanan keperawatan dengan kepuasan pasien di ruang paviliun RSUD Jend. Ahmad Yani Metro menyatakan kepuasan pasien terhadap pelayanan keperawatan dari 64 responden dengan penilaian puas sebanyak 44 responden $(68,75 \%)$, sedangkan penilaian kurang puas sebanyak 20 responden $(31,25 \%)$. Hal ini berarti pasien yang berada di ruang paviliun RSUD Jend. Ahmad Yani Metro lebih banyak memberikan penilaian puas terhadap pelayanan keperawatan.

Hasil penelitian ini sejalan dengan Nurhidaya (2014), tentang hubungan pelayanan keperawatan dengan kepuasan pasien rawat inap peserta jaminan kesehatan nasional (JKN) di RSUD Labuan Baji Makassar menyatakan kepuasan pasien terhadap pelayanan keperawatan dari penilian responden yang berjumlah 62 responden yang memberikan penilaian puas sebanyak 47 responden $(75,8 \%)$, sedangkan penilaian kurang puas sebanyak 15 dalam pelayanan keperawatan di ruang rawat inap interne pria dan wanita RSUD DR. Achmad Mochtar Bukit Tinggi menyatakan kepuasan pasien terhadap pelayanan keperawatan dari penilian responden yang berjumlah 85 responden dengan kategori penilaian puas $87,1 \%$, sedangkan kategori kurang puas $12,9 \%$. Hal ini berarti kepuasan pasien terhadap pelayanan keperawatan di ruang rawat inap interne pria dan wanita RSUD DR. Achmad Mochtar Bukit Tinggi dengan kategori tertinggi yang di berikan pasien dari 85 responden sebanyak $87,1 \%$ yang menyatakan puas terhadap pelayanan keperawatan.

Berdasarkan penjelasan diatas, peneliti berasumsi bahwa kepuasan pasien diruang rawat jalan Rumah Sakit Islam Siti Khadijah Palembang menyatakan sudah puas dengan pelayanan yang diberikan hal ini dibuktikan dengan kesopanan perawat pada saat melakukan pelayanan, kerjasama perawat dengan pasien dan keluarga, dan kerjasama antara perawat dengan tim medis lain untuk melakukan tindakan kepada pasien.

\section{Analisis Bivariat}

Analisis Pelayanan terhadap kepuasan pasien di Ruang Rawat Jalan RSI Siti Khadijah Palembang

Tabel berikut ini menjelaskan hasil analisis hubungan pelayanan terhadap kepuasan pasien di ruang rawat jalan Rumah Sakit Islam Siti Khadijah Palembang.

Tabe 3. Pelayanan terhadap kepuasan pasien di Ruang Rawat Jalan RSI Siti Khadijah Palembang

responden $(24,2 \%)$. 


\begin{tabular}{|c|c|c|c|c|}
\hline \multirow[b]{2}{*}{$\begin{array}{c}\text { Pelayanan } \\
\text { Keperawatan }\end{array}$} & \multicolumn{2}{|c|}{ Kepuasan Pasien } & \multirow[b]{2}{*}{ Jumlah } & \multirow{2}{*}{$\underset{\text { Value }}{P}$} \\
\hline & Puas & $\begin{array}{c}\text { Kurang } \\
\text { Puas }\end{array}$ & & \\
\hline Baik & 168 & 48 & 216 & \\
\hline Kurang Baik & 28 & 128 & 156 & 0,001 \\
\hline
\end{tabular}

Hal ini berarti lebih banyak responden yang menyatakan puas terhadap pelayanan keperawatan dari 62 responden di ruang rawat inap RSUD Labuang Baji Makassar. Penelitian yang dilakukan Andriani dan Putra (2016), tentang faktor-faktor yang berhubungan dengan kepuasan pasien. pada tabel 3 dapat dilihat bahwa kepuasan pasien terhadap pelayanan di ruang rawat jalan RSI Siti Khadijah Palembang dari 216 responden, menyatakan puas dan menerima pelayanan dengan baik sebanya 169 responden. Sedangkan 156 responden lainnya menyatakan kurang puas dengan pelayanan keperawatan kurang baik sebanyak 128 responden. Hasil uji Chi Square didapatkan $p$ value : 0,001 yang berarti bahwa terdapat hubungan antara pelayanan terhadap kepuasan pasien di Ruang Rawat Jalan RSI Siti Khadijah Palembang.

Hasil penelitian ini mendukung teori Darus (2018), yang menyatakan bahwa pelayanan keperawatan merupakan faktor yang paling penting untuk membentuk kepercayaan pelanggan atau pasien kepada pelayanan keperawatan sehingga tercipta loyalitas dan kepuasan pasien.

Hasil penelitian ini sejalan dengan Alamri (2015) dengan judul hubungan antara mutu pelayanan perawat dan tingkat pendidikan dengan kepuasan pasien peserta badan penyelenggara jaminan sosial (BPJS) kesehatan di ruang rawat inap Rumah Sakit Islam (RSI) Sitti Maryam Kota Manado, dengan hasil $p$ value $0,000=(\alpha=0,05)$, sehingga Ho ditolak, dapat disimpulkan bahwa ada hubungan antara mutu pelayanan perawat dengan kepuasan pasien peserta BPJS kesehatan di ruang rawat inap Rumah Sakit Islam (RSI) Sitti Maryam Kota
Manado.

Hasil penelitian yang dilakukan oleh Astuti, (2017). Mutu pelayanan keperawatan tergolong baik dengan persentase sebesar $89,3 \%$. Tingkat kepuasan pasien tergolong cukup puas dengan persentase sebesar $68,0 \%$. Hasil penelitian menunjukkan bahwa adanya hubungan antara mutu pelayanan keperawatan dengan kepuasan pasien di RS PKU Muhammadiyah Bantul dengan nilai $\mathrm{p}=0,005$ dan nilai $\mathrm{r}=0,319$.

Hasil penelitian ini juga sejalan dengan hasil penelitian yang dilakukan oleh Siwi, dkk (2017). terdapat hubungan variabel servicescape sebanyak 0,000 dan kualitas pelayanan sebanyak 0,000 termasuk signifikan terhadap kepuasan pasien Rumah Sakit Prof. R.D. Kandou Manado.

Dari penjelasan diatas peneliti berasumsi bahwa kepuasan pasien terhadap pelayanan adalah tenaga kesehatan dan perawat mampu dalam melakukan tindakan keperawatan yang benar, perawat mampu untuk melakukan pembinaan komunikasi yang baik kepada pasien dan perawat tanggap dalam memberikan tindakan saat pasien membutuhkan dan tanggap dalam menyelesaikan keluhan pasien. Dokter juga mampu memberikan informasi yang akurat terkait keluhan yang disampaikan oleh pasien. Tim administrasi yang kooperatif dalam menyampaian informasi serta ketangkasan semua pemberi pelayanan. Sehingga pasien percaya dan merasa puas terhadap pelayanan yang diberikan.

\section{KESIMPULAN}

Berdasarkan hasil penelitian yang telah dilakukan maka dapat disimpulkan bahwa

1. Responden mengungkapkan pelayanan yang diberikan oleh Rumah Sakit sudah 
baik yaitu sebanyak $216(58,1 \%)$ orang dari 372 orang responden.

2. $196(52,7 \%)$ orang responden menyatakan puas terhadap pelayanan yang diberikan.

3. Ada hubungan pelayanan terhadap kepuasan pasien di ruang rawat jalan RSI Siti Khadijah Palembang dengan $p$ value $0,001<0,005$.

\section{SARAN}

Berdasarkan hasil penelitin maka disarankan kepada rumah sakit islam siti khadijah untuk dapat mempertahankan dan meningkatkan pelayanan yang lebih baik lagi melalui system informasi manajemen terpadu rumah sakit terkini.

\section{UCAPAN TERIMAKASIH}

Penulis mengucapkan terima kasih kepada semua pihak yang telah membantu dan mendukung terlaksananya penelitian ini.

\section{DAFTAR PUSTAKA}

Andriani, A. 2017. Hubungan Mutu Pelayanan Kesehatan dengan Kepuasan

Pasien Diruangan Poli Umum Puskesmas Bukittinggi.

Jurnal Endurance: Kajian Ilmiah Problema Kesehatan, 2(1), 45-52.

Astuti, P. P. 2017. Hubungan mutu pelayanan keperawatan Dengan kepuasan pasien di rs pku muhammadiyah bantul.

Aida Andriani, SKM, Heru Aditia Putra. 2016. Fakor-Faktor yang Berhubungan dengan Kepuasan Pasien dalam

Pelayanan Keperawatan di Ruang Rawat Inap Interne Pria dan Wanita RSUD DR. Achmad Mochtar Bukit Tinggi.

Andi Nurhidaya. 2014. Hubungan Pelayanan Keperawatan dengan Kepuasan Pasien Rawat Inap Peserta Jaminan Kesehatan
Nasional (JKN) di RSUD Labuan Baji. [Skripsi]. Makassar : Fakultas Ilmu Kesehatan UIN Alauddin Makassar.

Asmuji. 2016. Manajemen Keperawatan: Konsep \& Aplikasi. Jogjakarta: ARRUZZ Media.

Azlika M. Alamri, Adisti A. Rumayar, Febi K. Kolibu. 2015. Hubungan antara Mutu Pelayanan Perawat dan Tingkat Pendidikan dangan Kepuasan Pasien peserta Badan Penyelenggara Jaminan Sosial (BPJS) Kesehatan di Ruang Rawat Inap Rumah Sakit Islam (RSI) Sitti Maryam Kota Manado. Jurnal. Ilmiah Farmasi - UNSRAT. Vol 4 No. 4; Hal 241 - 251.

Erista Kumalasari. 2017. Hubungan Kualitas Pelayanan Keperawatan dengan Kepuasan Pasien di Ruang Rawat Inap Bedah RSUD dr. Loekmono Hadi Kudus.

PROSIDING HEFA $1^{\text {st }}$.Kotler, Philip and Kevin Lane Keller, 2016: Marketing Management, $15^{\text {th }}$ Edition New Jersey: Pearson Pretice Hall, Inc.

Maria H. Bakri. 2017. Manajemen Keperawatan: Konsep dan Aplikasi dalam Praktik Keperawatan Profesional. Yogyakarta. Pustaka Baru Press.

Nursalam. 2016. Manajemen Keperawatan: Aplikasi dalam Praktik Keperawatan Profesional. Edisi 5. Jakarta: Salemba Medika.

Nursalam. 2016. Metodologi Penelitian Ilmu Keperawatan. Edisi 4. Jakarta: Salemba Medika.

Nuri Luthfiatil Fitri. 2016. Hubungan Persepsi Pasien pada Pelayanan Keperawatan dengan Kepuasan Pasien di Ruang Paviliun RSUD Jend. Ahmad Yani Metro. Wacana Kesehatan. Vol.1, No. 1 - 49.

Purwanto. 2017. Kepuasan Pasien Rawat Inap terhadap Pelayanan Perawat di RSUD. Tugu Rejo Semarang. Jurnal. Ilmiah Ners.

Roymond H. Simamora. 2018. Buku Ajar 
Manajemen Keperawatan. Jakarta: EGC.

Siwi, A. R., Supandi, A. S., \& Loindong, S. S. 2017. Pengaruh Servicescape dan Kualitas Pelayanan terhadap Kepuasan Pasien Instalasi Rawat Jalan pada Rumah Sakit Prof. Dr. RD Kandou Manado. Jurnal EMBA: Jurnal Riset Ekonomi, Manajemen, Bisnis dan Akuntansi, 5(2). 
